Article

\title{
An Integrated Framework on the Sustainability of SMEs
}

\author{
Adriana Burlea-Schiopoiu *(D) and Laurentiu Stelian Mihai
}

Faculty of Economics and Business Administration, University of Craiova, 13, Street A.I. Cuza, 200585 Craiova, Dolj, Romania; mihai.laurentiu@ucv.ro

* Correspondence: adriana.schiopoiu@feaa.ucv.ro; Tel.: +40-7221-195-174

Received: 25 September 2019; Accepted: 28 October 2019; Published: 30 October 2019

\begin{abstract}
The aim of this article is to investigate the relationship between the budget related to corporate social responsibility (CSR), Innovation and Training, defined as sustainable factors, and the financial results of small and medium sized enterprises (SMEs). The investigation is made by analysing the financial results from a sample of 200 SMEs from the South-West Region of Romania. The findings prove that SMEs can use training and innovation to improve the impact of CSR on their sustainability with a focus on positive financial indicators. The findings prove that corporate social responsibility (CSRBi), innovation (InnovBi), and training (TrainingBi) as sustainable factors are significantly and positively correlated with the following indicators: profit (Profit ${ }_{\mathrm{i}}$ ), profit per employee (Profit $E_{\mathrm{i}}$ ) and total expenditure (Expenses $\left.\mathrm{i}_{\mathrm{i}}\right)$, and it is negatively correlated with debt ratio $\left(\right.$ DebtR $\left._{\mathrm{i}}\right)$.
\end{abstract}

Keywords: small and medium sized enterprises; corporate social responsibility; innovation; financial performance; profit; debt ratio

\section{Introduction}

Since the 1972 United Nations Conference on the Human Environment, when the sustainable development term was launched and up to the present day, this term has been enriched with new attributes such as environmental issues and bio/green innovation related to ecological factors [1,2]. Thus, sustainable development became, for many companies, a goal in itself, integrated into their strategic mission and vision and now universally referred to as corporate social responsibility.

Most corporate social responsibility studies focused on large companies because large companies offer researchers a vast domain of their research, including good case studies (Google, Johnson and Johnson, and Ford Motor Company), as well as major ethical issues (Barclay's, Deutsche Bank, Inditex, and Nestle). Some companies offer both, such as the Volkswagen Group, which is involved in social responsibility practices but at the same time, was strongly affected by the Diesel gate scandal in 2015 [3].

The sustainability for small and medium sized enterprises (SMEs) consists of achieving a balance on the one hand between financial, human and material resources, and on the other hand with the social and economic environment in which it operates. Lack of financial resources and lack of time are often mentioned as factors that prevent SME to develop a sustainable strategy and to consider the investment in sustainability as a competitive advantage.

For large companies, operating in a competitive and turbulent environment is an accepted element of doing business, likewise, for small and medium sized enterprises (SMEs), the business environment can be both a challenge but also a source of opportunity. The challenges for SMEs include access to fewer resources (human, financial, physical and informational) and it can also be extremely difficult for SMEs to implement sustainable-driven innovation practices [4,5]. However, SMEs that take on 
the challenge of sustainable innovation may carve out new business opportunities and competitive advantage for their businesses.

This being said, we consider our study on SMEs appropriate, because it offers us the opportunity to analyse the advantages, disadvantages as well as the barriers and drivers of promoting sustainable development, at the small business level. We will investigate the relationship between the expenses and profit of SMEs from a sustainable point of view and we will discuss the factors that facilitate their sustainability.

SMEs from the two industries (Section F-construction companies and Section G-Wholesale and retail trade, maintenance and repair of vehicles and motorcycles) present a series of characteristics that contribute to their involvement in socially responsible and sustainable practices in the region. Thus, construction companies are socially responsible because, through their operations, they contribute either to the pollution (Harron Homes, Carillion) or the protection of the environment (Catterpillar, Dewalt), ensure the social and economic wellbeing of their communities and actively contribute to building the necessary infrastructure for the sustainable operation of SMEs from other industries.

In the South West Region of Romania, SMEs are an important source of employment and thus, our research aims to establish if there are direct correlations between the corporate social responsibility (CSR), innovation and training budgets and certain performance indicators (profit, profit/employee and debt ratio).

We base our research on financial indicators because, regardless of its size, any organization has a main purpose of making a profit. Under fierce competition and explosive development of technology, SMEs must maximize any competitive advantage created by human resources and which consists of training, innovation, and CSR.

The theoretical framework will be oriented to practice related to CSR and we will use the financial indicators for evaluating the effect of these practices on SMEs' sustainability.

The main research question is the following:

Which indicators of sustainable development—corporate social responsibility, innovation, and training occur in SMEs and how they impact the financial indicators?

To answer this question, we have employed quantitative research based on certain financial indicators, measured from 2010 to 2017.

Based on our results, we developed an integrated framework for the sustainable development of South-West Oltenia Region' SMEs, where we understand how sustainable indicators can impact the SMEs' financial results.

\section{Literature Review and Hypotheses}

\subsection{Social Responsibility and Financial Results of SMEs}

The most general understanding of corporate social responsibility (CSR), as defined by Vilke [6] is referring to an organization which is acting voluntarily (going beyond the laws and regulations) in order to fulfil social and environmental goals in its daily operations, and at the same time generate a win-win scenario that contributes to the sustainability of both the organization and society. Thus, CSR comprises the responsibility of various companies, public entities, and NGOs for their impact on society.

The European Commission (EC) defined CSR in its policy Communication on CSR in 2006 as a voluntary process adopted by companies to integrate social and environmental aspects at two levels as follows: (i) internal level in their business operations and (ii) external level through interactions with their stakeholders [7].

Aiming to fully meet their social responsibility, businesses, as lately suggested by the Commission, should have in place a process to integrate sustainable elements into their business strategy. When talking about CSR in general and the relationship between CSR practices and the financial performance of the company, most studies focus on large corporations, with few researchers choosing to approach 
this concept at SME level, mainly because the publicly available financial data from SMEs is quite scarce when compared to large, publicly listed companies which have to issue financial statements and earnings reports every quarter.

Recent studies on the relationship between CSR and SME's were not conclusive, thus suggesting the need for further research on this relationship due to the contribution of the small and medium sized enterprises to the global economy [8]. SMEs provide a good environment for CSR because of their multi-skilled workforces and successful local engagement [9]. Yet, many small business owners/managers believe that their social and environmental impacts are negligible $[10,11]$.

The literature is rich with studies regarding CSR in large companies, but not so many studies have focused on SMEs' approach to CSR.

Spence [12] describes SMEs as fortress enterprises, focused on operational duty and quite disconnected from the general business environment, reactively responding to urgent issues. Thus, most SMEs view CSR as a risky activity, an investment with no significant financial return [13,14]. Due to this reasoning, it is less likely for an SME to invest a significant amount of money in a CSR program, as they would receive less publicity for the social responsibility actions, as opposed to large companies [15].

Previous research on the SME-CSR relationship has tackled different issues of SMEs' involvement in CSR, such as firms' environmental practices [16,17], CSR barriers and opportunities [18-20], and how integrity and ethical practices can lead to competitive advantage [21-23].

Regarding the relationship between the CSR practices and the financial performance of SME's, previous studies fall into one of the following three categories:

1. Studies that show a positive correlation between CSR practices and financial performance [24,25]. These studies show that large CSR budgets lead to a significant return in terms of image, which eventually translates to better financial performance, the benefits thus outweighing the costs. Moreover, socially responsible SME's may have a better relationship with its stakeholders, thus improving the performance of the company.

2. Studies that find no significant correlation between CSR practices and financial performance [26,27].

3. Studies that show a negative correlation between CSR practices and financial performance [28], based on managerial opportunism hypotheses: managers can reduce CSR investments in order to increase short-term profitability. The main point here is that CSR investments are expensive and the returns (if any) are in the distant future and not easy to measure.

Russo and Perrini [29] explain why SMEs approach CSR differently to large companies:

- An SME has access to a limited pool of resources, a flexible organisational structure which easily adapts to local market challenges, and promotes informal relationships in both the internal and external environment,

- A large company has access to a diversified pool of resources, a more rigid organisational structure which contributes to a degree of inflexibility when it comes to local market challenges, and thus, is more internally oriented and more likely to promote formal relationships in both the internal and external environment.

In general (also suggestive for the Romanian SME environment), the level of social involvement in small and medium sized enterprises is quite low, compared to large companies. One of the reasons for this disparity is the financial constraints of an SME. Sharma [30] states that one of the reasons that larger companies are more likely to invest in a CSR activity is their ability to absorb fixed costs and the ease of access to capital and other resources. For example, a large company, with more than 250 employees can easily access a credit plan and create a team of 5-10 employees, who can get involved in a significant CSR campaign. An SME may find it difficult to get access to capital for this kind of 
investment, while its human resources may not have the capacity to be involved in CSR initiatives due to their operational duties.

Ashton, Russell and Futch [31] found that the majority of SMEs from the United States appear to be driven primarily by cost and competitiveness concerns, more than by social responsibility to implement green practices.

Many scholars through their research found that SMEs are reluctant to invest in CSR because of limited capital available and are more likely to invest in areas that improve the performance of their businesses vis-à-vis their business competitors such as product marketing and advertising [32-37].

SMEs are, by definition, are small businesses, but nevertheless, CSR activities may be important for them but their activities will be directly related to their limited resources [38]. Due to the difference in size and resources, SMEs are more likely to get involved in small social campaigns, with a local impact, rather than large, country wide activities, with a large impact and a heavy public relations (PR) campaign. SME's main goal in undertaking CSR initiatives is to promote their image in the local community, which can directly benefit their business activities $[39,40]$. Moreover, personal or individual reasons are among the important motivational factors to embark on CSR initiatives, thus highlighting the importance of the role of the SME's owner in influencing CSR initiatives and practices [41].

Even if involvement in CSR for SMEs is not easy and implies a number of challenges [42], it has been shown to provide a source of differentiation and visibility [43], to enhance their relationships with key stakeholders [44,45] through creation of trust with its stakeholders [46], and result in improved financial performance in most cases [47].

Although there are works covering CSR in European countries and most CSR literature is related to Anglo-Saxon countries with fewer investigations of CSR in other cultural contexts and a focus on large companies' information disclosure [48].

In Romania, the level of social involvement of small and medium sized enterprises falls in line with the above Anglo-Saxon model. While large companies such as Petrom, Reifessen Bank, CEZ and others have long term, nationwide CSR campaigns (Tara lui Andrei and Reifessen Pentru Comunitati), closely followed by successful PR campaigns, small and medium sized enterprises, if they get involved in social activities, they mostly support local NGOs and social causes [49].

Torugsa and O'Donohue [50] state that the increased interest towards CSR has led to numerous researchers studying how can a CSR strategy bring a competitive advantage to a company and influence its financial performance. Thus, CSR can add value to a firm's market performance and an example of this is socially responsible mutual funds, which are representative of socially responsible companies. Also, CSR activity has a significant impact on financial performance and CSR activity is less vulnerable to economic shocks, financial crises or environmental disasters [51].

Researchers found over a ten year time span and across countries from three continents (Asia, Europe, and North America) that socially responsible mutual funds had a significant positive return for their associated companies [52] and a significant positive effect in excess returns generated by the score of enhanced employee relationships [53].

Nowadays, CSR has become a critical aspect of a company's strategy and is closely related to the company's notoriety. Positive reputations usually lead to positive financial results/performance and are a result of a constant investment over time [54,55]. Moreover, CSR can bring added value to a company by way of added protection against negative events, even if it doesn't immediately lead to an increase in profits, because it helps mitigate the effects of economic shocks, financial crises or environmental disasters [56].

According to Venanzi and Fidanza [57], an SME is sustainable if it sets not only financial goals but also social and environmental goals as it aims to create value for its shareholders, in order to improve the quality of life and the effective use of invested resources. Moreover, the advantages of creating a sustainable company image can be one of the following: 
- Expansion to new markets, where clients also take into account the company's image and ethical codes, besides the quality and price of the products, which in the long term may lead to an increase in profitability,

- A better relationship with all its stakeholders, Better employee retention,

- Lower debt, as potential investors are more likely to fund a socially active company,

- Strategic alliances and partnerships.

Based on these theoretical arguments, we propose the following research hypotheses regarding the relationship between CSR budget and the financial results of SMEs:

Hypothesis 1. CSR budget is directly associated with SMEs financial results

Hypothesis 1a. CSR budget is positively associated with SMEs profit

Hypothesis $\mathbf{1 b}$. CSR budget is positively associated with SMEs profit per employee

Hypothesis 1c. CSR budget is negatively associated with SMEs debt ratio

\subsection{Innovation and Financial Results of SMEs}

Since Schumpeter [58] described entrepreneurs as individuals whose function was to carry out new combinations of means of production, innovation has been conceived as a key dimension of entrepreneurship [59]. Hence, innovation would represent a primary factor to differentiate genuine entrepreneurs from mere business owners [60].

Throughout the years, there have been many different definitions for innovation, many of them mentioning the novelty of the creation or the improvement it offers a new combination of old ideas or a minor change in an established process [61,62].

The definition of innovation is around the element of a new idea or behaviour [63] which over time can give rise to significant positive outcomes that can be demonstrated through the examination of time-cost-quality variables of the innovation [64].

The research on innovation proved that firms rely on external sources of innovation to create value, such as externally sourced technology [65], including semiconductors [66], software [67], and cellular phones [68], as well as low-technology industries like construction and textiles [69]. As a result, having access to an external form of innovation can improve a company's performance by increasing product quality, improve price competitiveness, improve business processes, gain valuable knowledge, reduce costs and better understand the market, thus improving the company's capacity to learn and innovate [70,71].

The relationship between the introduced concepts of innovation and CSR has been widely studied in the literature and some researchers arrived at the conclusion that the benefits associated with external sources are conditioned by the organizations dimensions and only multinational organizations are able to expand their R\&D activities across borders within their global value chains [72-74].

Considering that innovation is usually defined in relation to the improvement of products, services and management processes [75,76], CSR can be considered a non-technological innovation in the company's management, as it involves introducing new changes in the established processes.

Bansal [77] showed a significant relationship between innovation (R\&D) expenditure and CSR since companies must apply the principles of corporate responsibility to their products, processes, and production practices that require changes in the technology used, and this may involve investing in R\&D [78].

Another positive relationship is well established between innovation (R\&D) expenditure and CSR strategies, as they both tend to lead to product/service or process innovation which may give rise to a positive public perception of the company through enhanced branding and closer positive relationships with its internal and external stakeholders. Organizations can benefit from new 
business opportunities derived from environmental and social products and increased demand for their products. New or improved working conditions that foster creativity and innovation, based on increased employee participation and confidence in the organization can also lead to business performance [79]. Therefore, innovation has a mediating role between CSR and competitive advantage and increasing innovation could become a competitive success, enhancing the effect that CSR already exerts on the SME's competitiveness.

Another sustainable innovation definition cites a relationship between new ideas or behaviours oriented to the protection of the environment [80]. Recently, Grayson et al. [81] suggest an integrated concept of corporate sustainability (S2AVE), which places an emphasis on innovation as the means to add value while considering the environment and society at large.

The negative impacts of business activities on society and the environment can be reduced by innovation $[82,83]$ by putting into place environmental policies and regulations that nurture and encourage innovative strategies to protect the environment [84].

McWilliams and Siegel [85] arrived at the conclusion that R\&D investments and CSR are highly correlated, because they both are associated with product and process innovation and there is a significant positive correlation between compliance expenditure and $R \& D$ budgets, because innovation is perceived as a factor that neutralizes the CSR effect on profitability [86]. The paradox of the relationship between R\&D and CSR is the fact that both can be considered as a form of technological investment which may lead to an increase in technological capabilities (i.e. patents) and in organizational innovation [87] because R\&D investment is considered to be a critical factor CSR research [88].

Through CSR initiatives, companies have the opportunity to form new relationships with environmental organizations, research institutes and community leaders [89], because that social initiatives enable a firm to develop multidimensional stakeholder relationships [90] and to have easier access to information, ideas and knowledge that their own stakeholders voluntarily share with it [91]. The employees' willingness to share and combine knowledge contributes to an improvement in the capacity of the organization to innovate [92]. The employees play an important role in the adoption of collaborative technologies in order to innovate because these collaborative technologies are positively related to innovation in SMEs and also positively related to internet technologies and SME innovation and performance [93].

Unlike large enterprises, small and medium sized companies have scarce resources, thus giving rise to the need for cooperation in innovation in order to survive in the market [94]. We consider that SMEs can profit through participation in networks and engaging in strategic partnerships with a large variety of external actors (other private companies, business hubs, universities, research centres, and public authorities). Due to their flexible organizational structures, SMEs can use local networks to obtain size-related advantages [95].

The research of Fukugwa [96] on Japanese SMEs, suggested that networking is a significant aspect in an SME's ability to innovate, because it provides access to expertise and resources and Xie, Zeng and Tam [97] found a positive correlation between external sources and innovation performance based on their study of 137 Chinese manufacturing SME's. The external knowledge sources of SMEs are better suited to innovate and represent an opportunity for SMEs to overcome the challenges generated by the business environment [98].

Innovation creates value for organizations and one of its most important competitive advantages, as Schumpeter [58] suggested that SMEs are likely a source of innovation because innovation has the potential for SMEs to gain financial advantage through a temporary establishment of a monopoly on a newly created technology or process. Clients may be attracted to the unique aspect of the innovative ideas and thus, innovative SMEs benefit from high brand loyalty in their customers and a reduced-price sensitivity of demand [99].

In order to survive, SMEs can profit from their advantages, such as organizational flexibility, their ability to create and use external networks [100], operational knowledge and expertise, customer loyalty [101], development of innovative products and services and creating new demand [102]. 
The positive relationship between innovation and SMEs' competitive advantage was established by many scholars which demonstrated that organizational innovation in general and more specifically, product innovation had a positive impact on an organization's competitive advantage [103].

Successful companies within an industry must focus on new product developments which may allow them to achieve the best possible results within their market [104], and innovation provides organizations with abilities, skills, competencies, and processes to survive and perform [105]. Innovation can be the main driver for companies to prosper, grow and sustain high profitability [106], and successful innovation activities help SMEs to establish a competitive position in the market, enhancing its competitive advantage and, consequently, improved business performance [107].

As a result, we propose the following hypotheses regarding the relationship between the innovation investment budget and the SME's financial results.

Hypothesis 2. Innovation budget is directly associated with SMEs financial results

Hypothesis 2a. Innovation budget is positively associated with SMEs profit

Hypothesis $\mathbf{2 b}$. Innovation budget expenditure is positively associated with SMEs profit per employee

Hypothesis 2c. Innovation budget expenditure is negatively associated with SMEs debt ratio

\subsection{Training, Development and Financial Results of SMEs}

In the strategic management literature, innovation is defined as the output variable of human resources investment [108-110], and researchers have found evidence of a relationship between human resources practices that promote on the job development (generation of new ideas while solving operational tasks) and formal training and development as a predictor of innovation in organizations [111].

Sheehan [112] analysed the relationship between human resources management (HRM) and the United Kingdom SMEs' performance and he highlighted the fact that the more an SME invests in formal HRM activities, the better their organizational performance and innovation become. The findings of Sheenan were confirmed by Anonioli and Della Torre [113] and they arrived at the conclusion that training and development, together with strategic human management practices are the only practices significantly correlated with all three performance indicators: innovation, financial results and employee turnover.

The negative tendency towards investment in training was identified by Kotey and Folker [114] who highlighted that despite the fact that SME's owner/managers tend to acknowledge the importance of training and development in improving a company's performance, SMEs are generally reluctant to provide formal employee training.

The training of employees in SMEs is an unplanned activity and usually achieved through on the job training and there is usually little or no provision for employee development that involves releasing the employee from the job for short periods of time [115]. Owners-managers of SMEs have the responsibility for a systematic approach to training based on needs assessment of the employees [116,117], but, unfortunately the owners-managers perceive formal training as too expensive, they tend to take into account the cost of the training as well as the lost productivity while the employee attends the training [118,119].

The SMEs usually think on a short-term horizon, due to the high levels of risk and uncertainty they face in their daily activities. Taking this into account and considering that the benefits from training and development are usually long-term, investment in employee training and development can appear unattractive for SMEs. Furthermore, SMEs face the risk of losing the trained employees to competitors, mainly because of the limited internal promotion opportunities that an employee has within their own organizations.

As a conclusion, it is difficult to establish a direct positive relationship between training and performance therefore, owners-managers are reluctant to invest in formal training programs [120], 
because SME owners-managers prefer informal training because it's less expensive, it can be integrated in the daily operations (thus not losing productivity), it targets the employees' specific needs and expectations, and the employees learn in the context in which their skills are used. They develop diverse skills in order to solve the diverse problems that appear during the day-to-day operation of a small company, thus leading to the development of a multiskilled labour force, more useful to SMEs than a narrowly specialized staff [121]. In order to grow and perform, SMEs need skills, knowledge, and resources [122] and the employee is the most significant asset of an SME and a source of potential competitive advantage to any company [123].

SMEs can use their resource specific characteristics (skills, attitudes, and knowledge) in order to enable competitive advantage, and it is important that the SME owners-managers understand the relevance of employee training within the SME and to accept it as a process to enhance SME performance through improved productivity and profitability.

There are a number of empirical evidences which, based on the above-mentioned aspects, have studied the correlation between employee training and organizational performance. Studies from Latham and Frayne [124], McLinden, Davis, and Sheriff [125], Connerley [126], Klein and Weaver [127] examined the relationship between employee training and organizational performance by comparing the productivity of employees which have partaken in training and development programs and those who did not. Burlea-Schiopoiu and Burdescu [128], Krueger and Rouse [129], Birdi, Clegg, Patterson, Robinson, Stride, and Wall [130] examined whether the training and development of employees have implications for the company's performance as a whole, as measured by certain financial indicators. Most of these studies provided evidence that there is a significant positive relationship between employee training and organizational performance.

Aragon and Valle [131] examined if the incidence and intensity of the training influence the organizational performance and found that a number of studies that addressed this issue came to different conclusions. They also stated that these conclusions are difficult to compare since the studies used different methodologies and variables.

Regarding the study of training effectiveness, Murray and Raffaele [132] analysed the impact on the performance of a number of employees who attended training programs on behalf of their company. Tzafrir [133] measured the effectiveness of training through the percentage of employees who participate in training sessions. Delaney and Huselid [134] analysed the relationship between training and performance and created an index that included the number of workers who were involved in formal training in the previous two years as a way to measure training effectiveness. From these afore-mentioned studies, only Black and Lynch's [135] study failed to find a positive relationship between staff training and the company's performance.

The studies on training effectiveness focused on two main problems: training time and the resources employed in the training programs. In their studies, Lengermann [136], Schonewille [137] analysed the impact of training time on performance by measuring training time as the average hours of training per employee during a certain period of time (usually one year). Other researchers used different measures: Lynch [138] used weeks of training, Bartel [139] used the year in which the training was developed, Bartel [140] measured training time as the number of days spent in training in one year for every employee, Kidder and Rouiller [141] used the number of hours the training sessions lasted while Barrett and O'Connell [142] used the percentage of working days dedicated to measuring training budgets as a percentage of total payroll cost, while including an estimation of the lost productivity while the employee attends training. From the afore-mentioned studies, only Aragon et al. [143] didn't find a positive relationship between training time and organizational performance.

Another variable commonly found in recent studies is the company's training budget (the cost of all training undertaken in a one-year period). The main limitation of this measure is the fact that this information is not publicly available, and companies may be reluctant in disclosing it or disclosing false information [144]. Furthermore, Frazis, Gittleman, Horrigan and Joyce [145] stated that many companies were not sure what kind of costs to include when they measured this variable. The same 
problem arises in the theoretical framework, as researchers do not agree on which costs should be included in a company's training budget. For example, D'Arcimoles [146] considers that the training budget should only include formal costs, while Murray and Raffaele [132] have a broader definition of the term, including, besides direct training costs, the following: travel and accommodation, facilities, consulting fees, lost productivity due to employees' not working, trainer fees, training materials, and other miscellaneous costs.

Despite these broad definitions of training budgets, most studies have found a strong positive correlation between the training budget and the company's performance. For the purpose of the study, we included in the training and development costs only the direct costs related to training.

Taking into account the above elements, we stated the following hypotheses:

Hypothesis 3. Training and development budget are directly associated with the SMEs financial results

Hypothesis 3a. Training and development budget are positively associated with the SMEs profit

Hypothesis 3b. Training and development budget are positively associated with the SMEs profit per employee

Hypothesis 3c. Training and development budget are negatively associated with the SMEs debt ratio

Figure 1 depicts our research model by showing the link between three sustainable indicators (corporate social responsibility, innovation, and training) and their effects on financials results of SMEs (profit, profit per employee and debt ratio) as predictors of sustainable development and competitive advantage.

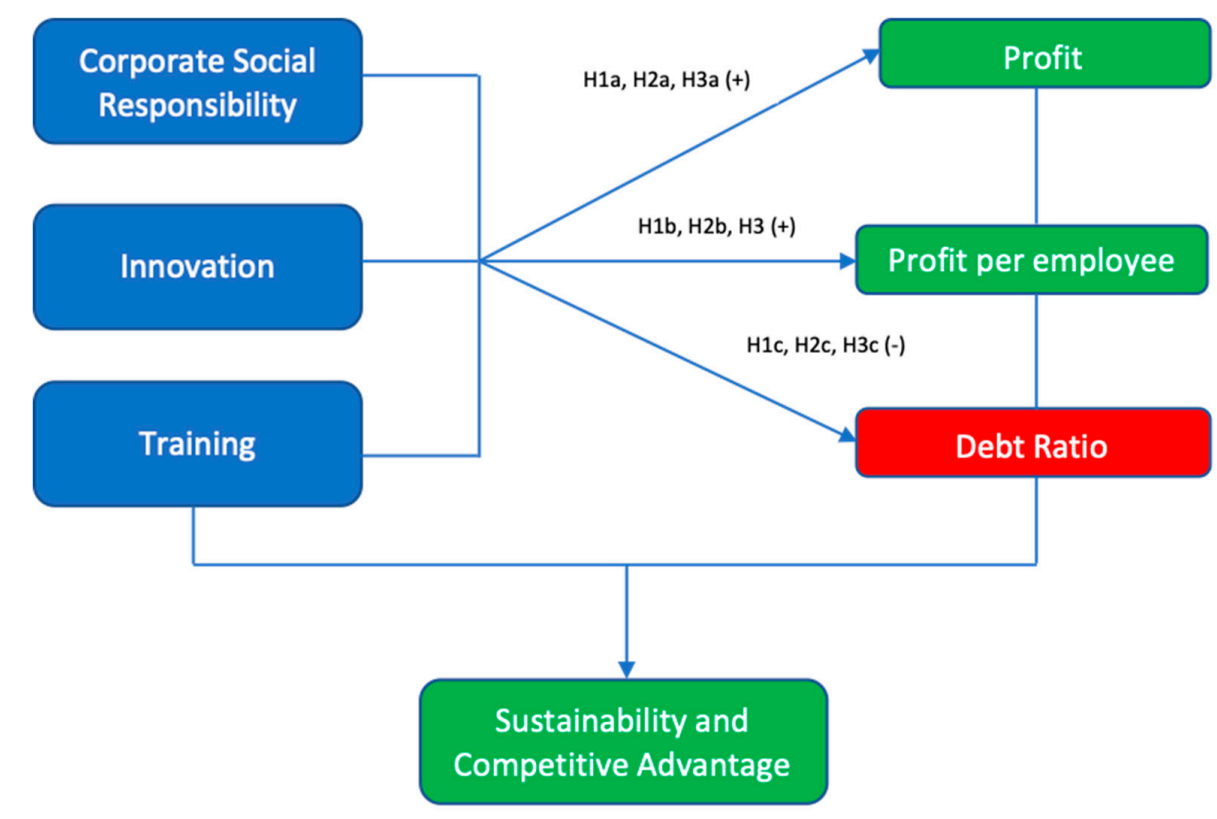

Source: our contribution

Figure 1. Sustainable hypothesized research model for small and medium sized enterprises (SMEs).

\section{Research Methods}

The study is based on an analysis of SMEs from the South-West Oltenia Region, one of the eight Romanian development divisions created in 1998 (North West, Centre, North East, South East, South Muntenia, West, Bucharest Ilfov). 


\subsection{Sample}

In the South-West Oltenia Region of Romania, according to the data publicly available on the County Statistics Office of Dolj [147], small and medium sized enterprises represent more than $99 \%$ of the total number of companies. Thus, from the 14,950 companies that were active in 2017, 14,901 were small and medium sized enterprises according to the EU definition (less than 250 employees, less than $€ 50$ million turnover and less than $€ 43$ million total assets) and 49 were large companies. From these 14,901 SMEs, 13,290 were micro-enterprises (less than 10 employees, less than $€ 2$ million turnover and total assets), 1,407 were small enterprises (between 10 and 49 employees, between $€ 2$ and $€ 10$ million turnover and total assets), while only 204 were medium sized enterprises (between 50 and 249 employees, between $€ 10$ and $€ 50$ million turnover and between $€ 10$ and $€ 43$ million euro total assets).

Regarding the industry, $47.14 \%$ of the total number of SME's were represented by two industries: Section F-Construction (1087 SMEs structured as following: 917 micro-enterprises, 152 small enterprises and 18 medium sized enterprises), Section G-Wholesale and retail trade, maintenance and repair of vehicles and motorcycles (5.938 SMEs structured as following: 5,420 micro-enterprises, 470 small enterprises and 48 medium sized enterprises).

In order to conduct our research, we analysed 200 SMEs from the South-West Region of Romania, which were selected based on the following criteria:

(1) It is from one of the main industries from the region, according to data from the Dolj Statistics County Office [147],

(2) The company must have been operational for of whole period 2010 to 2017,

(3) The company must have allocated for each year from 2010 to 2017, a specific budget for CSR, innovation or training.

Our sample, taking into account the industry code had the following structure: Section F-construction companies-40 SMEs (20\%), and Section G-Wholesale and retail trade, maintenance and repair of vehicles and motorcycles-160 SMEs (80\%).

\subsection{Variables}

The variables used in our study are explained in Table 1.

Table 1. Variable Definitions.

\begin{tabular}{cl}
\hline Code & \multicolumn{1}{c}{ Variable } \\
\hline CSRB $_{\mathrm{i}}$ & $\begin{array}{l}\text { Corporate Social Responsibility budget—CSR costs that include, but not limited to expenditure made by } \\
\text { the entity in relation to social responsibility initiatives, including donations, sponsorships and charity } \\
\text { events (in RON) }\end{array}$ \\
\hline InnovB $\mathrm{i}_{\mathrm{i}}$ & $\begin{array}{l}\text { Innovation budget—expenditure that includes, but not limited to R\&D investment, industry conferences, } \\
\text { networking events (in RON) }\end{array}$ \\
\hline TrainingB $_{\mathrm{i}}$ & $\begin{array}{l}\text { Training budget—expenditure that includes all costs made by the entity regarding the training and the } \\
\text { development (internal or external) of employees (in RON). }\end{array}$ \\
\hline NoEmp $_{\mathrm{i}}$ & The number of employees—-the average number of employees for each entity during a fiscal year \\
\hline Profit $_{\mathrm{i}}$ & The profit-The Gross Profit/Loss based on the difference between Total Income and Total Costs (in RON) \\
\hline Profit $_{\mathrm{i}}$ & The profit per employee-Gross Profit/Loss divided by the number of Employees (in RON) \\
\hline Expenses $_{\mathrm{i}}$ & $\begin{array}{l}\text { The total expenditure-all the expenditure (operational, financial and extraordinary) that a company had } \\
\text { registered during the fiscal year }\end{array}$ \\
\hline DebtR $_{\mathrm{i}}$ & The debt ratio-Total Debts divided by Total Assets \\
\hline &
\end{tabular}

Based on the financial data, this study extracted seven performance indicators pertaining to the following two aspects: profit (Profit ${ }_{i}$ and ProfitE $\left.E_{i}\right)$, expenditure $\left(\mathrm{CSRB}_{\mathrm{i}}\right.$, InnovB $\mathrm{B}_{\mathrm{i}}$, Training $\mathrm{B}_{\mathrm{i}}, \mathrm{DebtR}_{\mathrm{i}}$, and Expenses ${ }_{\mathrm{i}}$ ). 
Profit is the most important indicator because it reflects an SME's performance over the period 2010 to 2017 and the fluctuation in profit on a year to year basis, we analyse the correlation between profit and three budgets (state what the budgets are) that, if they are efficiently/effectively used, they can turn into profit, in the near future.

\section{Results and Discussions}

The Descriptive Statistics of variables used in our research are explained in Table 2.

Table 2. Descriptive Statistics of Variables.

\begin{tabular}{ccccc}
\hline Variables & Minimum & Maximum & Mean & Std. Deviation \\
\hline CSRB $_{\mathrm{i}}$ & 1035.1 & $5,888,706.3$ & $263,477.6$ & $709,451.1$ \\
\hline InnovB $_{\mathrm{i}}$ & 659.7 & $7,633,160.5$ & $304,997.5$ & $811,555.2$ \\
\hline TrainingB $_{\mathrm{i}}$ & 504.8 & $6,988,186.0$ & $260,007.6$ & $737,629.7$ \\
\hline NoEmp $_{\mathrm{i}}$ & 2 & 175 & 22.7 & 27.0 \\
\hline Profit $_{\mathrm{i}}$ & $-2,094,900.4$ & $3,633,092.3$ & $155,397.5$ & $434,005.3$ \\
\hline DebtR $_{\mathrm{i}}$ & 0.05 & 5.4 & 0.85 & 0.77 \\
\hline ProfitE $_{\mathrm{i}}$ & $-56,921.3$ & $80,654.1$ & 4959.7 & $13,481.0$ \\
\hline Expenses $_{\mathrm{i}}$ & $121,279.4$ & $135,810,303.6$ & $7,269,477.5$ & $1,5417,940.7$ \\
\hline
\end{tabular}

Source: Authors' calculation from research data.

The Mean number of employees was 22.74, with a minimum of 2 employees and maximum of 175 employees (see Table 2) and the mean profit was 155,397.5 (RON) lower than the mean of budgets allocated for Corporate Social Responsibility (263,477.6 RON), Innovation (304,997.5 RON) and Training (260,007.6 RON).

From the study of the three budget variables, we can see that the largest budget was for innovation, followed by CSR and then training (the difference between CSR and training was minimal).

We tested the structural model and the multi-item interval scales were used to assess the use of this technique as a strategic practice of SMEs [148].

We controlled for the size of SMEs (number of employees) and also for industry (constructions and wholesale and retail trade, maintenance and repair of vehicles and motorcycles) to rule our structural model.

Multiple regression analysis estimates that effect of the three covariates (corporate social responsibility budget- $\mathrm{CSRB}_{\mathrm{i}}$, innovation budget-InnovB $\mathrm{B}_{\mathrm{i}}$, and training budget-Training $\mathrm{B}_{\mathrm{i}}$ ) on the number of employees $\left(\mathrm{NoEmp}_{\mathrm{i}}\right)$ and on the financial indicators (profit-Profit ${ }_{\mathrm{i}}$, profit by employee-Profit $E_{i}$, expenses-Expenses ${ }_{i}$, and debt ratio-Debt $R_{i}$ ).

Our analysis continued with three Model Summaries for a set of three dependent variables: $\mathrm{CSRB}_{\mathrm{i}}$ (Model 1), InnovB $B_{i}$ (Model 2), and TrainingB $B_{i}$ Model 3) in order to evaluate several combinations of control variables until a particular set led to the largest possible $\mathrm{R}^{2}$.

Furthermore, we applied the Durbin-Watson test in order to verify the existence of independent errors (Durbin and Watson, 1951). Thus, we calculated how Profit ${ }_{i}$, DebtR $_{i}$, ProfitE $_{i}$, and Expenses E $_{i}$ variables predicted the subsequent increase of the CSRB $_{i}$, (Table 3), InnovB ${ }_{i}($ Table 4$)$ and Training $B_{i}$ (Table 5) in SMEs.

Table 3. Model Summary ${ }^{\mathrm{b}}$ for $\mathrm{CSRB}_{\mathrm{i}}$ (corporate social responsibility).

\begin{tabular}{lccccc}
\hline Model & $\mathbf{R}$ & R Square & Adjusted R Square & Std. Error of the Estimate & Durbin-Watson \\
\hline 1 & $0.986^{\mathrm{a}}$ & 0.972 & 0.971 & $119,964.7$ & 1.876 \\
\hline $\begin{array}{l}\text { a. Predictors: (Constant), DebtR } \\
\text { calculation from research data. }\end{array}$
\end{tabular}




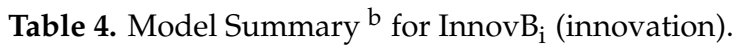

\begin{tabular}{cccccc}
\hline Model & $\mathbf{R}$ & R Square & Adjusted R Square & Std. Error of the Estimate & Durbin-Watson \\
\hline 2 & $0.987^{\text {a }}$ & 0.975 & 0.975 & $129,299.7$ & 1.921 \\
\hline \multicolumn{5}{c}{${ }^{\text {a }}$. Predictors: (Constant), DebtR ${ }_{\mathrm{i}}$, Profit $_{\mathrm{i}}$, Profit $_{\mathrm{i}}$, Expenses $_{\mathrm{i}},{ }^{\mathrm{b}}$. Dependent Variable: InnovB $_{\mathrm{i} .}$}
\end{tabular}

Table 5. Model Table 4 Model Summary ${ }^{\mathrm{b}}$ for Training $\mathrm{B}_{\mathrm{i}}$.

\begin{tabular}{|c|c|c|c|c|c|}
\hline Model & $\mathbf{R}$ & R Square & Adjusted R Square & Std. Error of the Estimate & Durbin-Watson \\
\hline 3 & $0.988^{a}$ & 0.976 & 0.976 & $115,323.9$ & 2.077 \\
\hline
\end{tabular}

The values of the multiple correlation coefficient $(\mathrm{R})$ between the predictors and the dependent variable CSRB $_{i}$ registered a high value (0.986), which shows a strong influence of all predictors on the $\mathrm{CSRB}_{\mathrm{i}}$ of the SMEs.

The value of $R^{2}$ measures how much of the variability in the dependent variable is accounted for by the predictors. In our model, its value is (0.972), which means that the predictors account for $97.2 \%$ of the variation of the SMEs' CSRB .

The adjusted $R^{2}$ offers us details about the degree of the generality of our model and its value is very close to the value of $R^{2}$ (the difference between the values is 0.001 ) indicating that the cross-validity of our models is very good.

From the analysis of Table 4, we can see that the values of the multiple correlation coefficient $(\mathrm{R})$ between the predictors and the dependent variable Innov $B_{i}$ registers a high value (.987), which shows a strong influence of all predictors on the Innov $B_{i}$ of the SMEs.

For our model, the value of the $\mathrm{R}^{2}$ is $(0.975)$, which means that the predictors account for $97.5 \%$ of the variation of the SMEs InnovB $B_{i}$. Moreover, the value is the same for both $\mathrm{R}^{2}$ and adjusted $\mathrm{R}^{2}$ indicating that the cross-validity of our models is very good.

An analysis of Table 5 proves that the values of the multiple correlation coefficient $(\mathrm{R})$ between the predictors and the dependent variable Training $B_{i}$ registers a high value $(0.988)$, which shows a strong influence of all predictors on the Training $B_{i}$ of the SMEs.

The value of the $\mathrm{R}^{2}$ is $(0.976)$, which means that the predictors account for $97.6 \%$ of the variation of the SMEs Training $B_{i}$. The value is the same for both $R^{2}$ and adjusted $R^{2}$ indicating that the cross-validity of our models is very good.

The statistical analysis unveils that Training $B_{i}$ is the variable with the highest level of influence $\left(0.988^{\mathrm{a}}\right)$ on the other indicators, followed by InnovBi, $\left(0.987^{\mathrm{a}}\right)$ and $\operatorname{CSRB}_{\mathrm{i}}\left(0.986^{\mathrm{a}}\right)$. The three variables influence the dependent variable to a similar extend, which comes to confirm other research findings showing that the sustainability of SMEs is highly dependent on their financial performance $[42,149]$.

The significance $R^{2}$ was tested using F-ratio which is significant with a probability of less than 0.001 [150]. For our models, this change was significant for Model 1, Model 2 and Model 3 (0.000).

We observe that the value of the Durbin-Watson test is between 1.876 (Model 1) and 2.077 (Model 3) which demonstrates a serial correlation between errors because a value less than 1 or a value greater than 3 is problematic for the model validity.

The Durbin-Watson test value stays within the 1.5-2.5 reference interval $[150,151]$. Thus, the hypothesis regarding the lack of autocorrelation between the residuals of the multiple regression model is validated.

The regression results of our models suggest that $\mathrm{F}$ values are significant at the 0.000 level, indicating the regression analysis is meaningful $\left(F\right.$ for $\mathrm{CSRB}_{i},=1691.2, \mathrm{~F}$ for InnovB $B_{i}=1911.2$, and $\mathrm{F}$ for Training $\left.B_{i}=1986.6\right)$. The following variables: Profit $E_{i}$, Profit $_{i}$, Expenses $_{i}$ are found to be positively associated with SMEs' sustainable factors $\left(\mathrm{CSRB}_{\mathrm{i}}\right.$, InnovB $\mathrm{B}_{\mathrm{i}}$, and Training $\left.\mathrm{B}_{\mathrm{i}}\right)$ and the variable Debt $\mathrm{R}_{\mathrm{i}}$ is found to be negatively associated with SMEs sustainable factors. SMEs have limited and often lack financial resources and as a consequence the resources allocated for sustainable activities are not provided in their annual budgets. 
Pearson's correlation coefficient can take values between 0 (no effect) and 1 (perfect effect) [152]. It is also important to discuss if the coefficient is positive or negative because it indicates the direction of the relationship between the variables (Table 6).

Table 6. Correlations between Variables.

\begin{tabular}{ccccccccc}
\hline Correlation & Variables & CSRB $_{\mathbf{i}}$ & InnovB $_{\mathbf{i}}$ & TrainingB $_{\mathbf{i}}$ & DebtR $_{\mathbf{i}}$ & Profit $_{\mathbf{i}}$ & ProfitE $_{\mathbf{i}}$ & Expenses $_{\mathbf{i}}$ \\
\hline \multirow{2}{*}{$\mathbf{C S R B}_{\mathbf{i}}$} & Pearson Correlation & 1 & $0.982^{* *}$ & $0.985^{* *}$ & -0.113 & $0.650^{* *}$ & $0.196^{* *}$ & $0.985^{* *}$ \\
\cline { 2 - 9 } & Sig. (2-tailed) & & 0.000 & 0.000 & 0.113 & 0.000 & 0.005 & 0.000 \\
\hline \multirow{2}{*}{ InnovB $_{\mathbf{i}}$} & Pearson Correlation & $0.982^{* *}$ & 1 & $0.987^{* *}$ & -0.117 & $0.685^{* *}$ & $0.209^{* *}$ & $0.986^{* *}$ \\
\cline { 2 - 9 } & Sig. (2-tailed) & 0.000 & & 0.000 & 0.100 & 0.000 & 0.003 & 0.000 \\
\hline \multirow{2}{*}{ TrainingB } & Pearson Correlation & $0.985^{* *}$ & $0.987^{* *}$ & 1 & -0.110 & $0.684^{* *}$ & $0.203^{* *}$ & $0.986^{* *}$ \\
\cline { 2 - 9 } & Sig. (2-tailed) & 0.000 & 0.000 & & 0.121 & 0.000 & 0.004 & 0.000 \\
\hline \multirow{2}{*}{ DebtR $_{\mathbf{i}}$} & Pearson Correlation & -0.113 & -0.117 & -0.110 & 1 & $-0.178^{*}$ & $-0.194^{* *}$ & -0.123 \\
\cline { 2 - 9 } & Sig. (2-tailed) & 0.113 & 0.100 & 0.121 & & 0.011 & 0.006 & 0.083 \\
\hline \multirow{2}{*}{ Profit $_{i}$} & Pearson Correlation & $0.650^{* *}$ & $0.685^{* *}$ & $0.684^{* *}$ & $-0.178^{*}$ & 1 & $0.582^{* *}$ & $0.676^{* *}$ \\
\cline { 2 - 9 } & Sig. (2-tailed) & 0.000 & 0.000 & 0.000 & 0.011 & & 0.000 & 0.000 \\
\hline \multirow{2}{*}{ ProfitE $_{\mathbf{i}}$} & Pearson Correlation & $0.196^{* *}$ & $0.209^{* *}$ & $0.203^{* *}$ & $-0.194^{* *}$ & $0.582^{* *}$ & 1 & $0.234^{* *}$ \\
\cline { 2 - 9 } & Sig. (2-tailed) & 0.005 & 0.003 & 0.004 & 0.006 & 0.000 & & 0.001 \\
\hline \multirow{2}{*}{ Expenses $_{\mathbf{i}}^{*}$} & Pearson Correlation & $0.985^{* *}$ & $0.986^{* *}$ & $0.986^{* *}$ & -0.123 & $0.676^{* *}$ & $0.234^{* *}$ & 1 \\
\cline { 2 - 9 } & Sig. (2-tailed) & 0.000 & 0.000 & 0.000 & 0.083 & 0.000 & 0.001 & \\
\hline
\end{tabular}

** Correlation is significant at the 0.01 level (2-tailed). ${ }^{*}$ Correlation is significant at the 0.05 level (2-tailed). Source: Authors' calculation from research data.

Correlated with $\operatorname{CSRB}_{\mathrm{i}}\left(0.982^{* *}\right)$ and with Training $\mathrm{B}_{\mathrm{i}}\left(0.987^{* *}\right)$, InnovB $\mathrm{B}_{\mathrm{i}}$ has the potential to successful position SMEs in niche markets. Hoffrén and Apalajahti [153] consider that innovation, especially radical innovation has a positive impact on the SMEs' sustainability because it highlights the owner-manager's entrepreneurial behaviour.

Compared to the other indicators, the analysis demonstrates a statistically significant causal effect on most performance indicators, except for DebtR $i$ which demonstrates that an increase in expenses limits the DebtR $i$ of SMEs.

The analysis of the findings suggests that all the independent factors (the predictors) contributed in a significant way to explaining the dependent variable (the level of statistical significance is lower that 0.05 or $5 \%$ for all factors). Moreover, we observed that between the value of the Profit ${ }_{i}$ and the $\mathrm{CSRB}_{\mathrm{i}}$, there is a direct influence relationship.

Our findings prove that CSRBi is significantly and positively correlated with the following indicators: Expenses $\mathrm{i}_{\mathrm{i}}$, Profit $\mathrm{i}_{\mathrm{i}}$, and Profit $\mathrm{E}_{\mathrm{i}}$, and it is negatively correlated with $\operatorname{DebtR}_{\mathrm{i}}$. The fact that the stronger correlation is between $\operatorname{CSRB}_{i}$ and Expenses ${ }_{i}(0.985)$ and the stronger negative one is between $\mathrm{CSRB}_{\mathrm{i}}$ and DebtR $\mathrm{R}_{\mathrm{i}}(-0.113)$, indicates that the $\mathrm{CSRB}_{\mathrm{i}}$ is an indicator that contributes to the limitation of DebtR $R_{i}$ of SMEs. Analysing the relationship between $\operatorname{CSRB}_{i}$ and the other indicators leads us to the conclusion that $\mathrm{CSRB}_{i}$ contributed significantly and in a positive way to the increase in profit and a decrease in expenses [154].

During the years the SMEs kept allocating a budget for sustainable activities and it is proved by the positive correlation between $\mathrm{CSRB}_{\mathrm{i}}$ and $\operatorname{Profit}_{\mathrm{i}}(0.196)$ and by the results of the research of Deng and Long [155] that consider the value of financial performance as a boundary.

SMEs can use training and innovation to improve the impact of CSR on their sustainability with a focus on positive financial indicators (i.e. a slow but steady growth of profit according to the degree of awareness and implementation of sustainability strategies and policies). The external environment and the public community might pressure SME owners to engage in CSR activities, in order to encourage the connection between the triple-bottom-line and the financial results. This is underlined by the results of the Irish Small and Medium Enterprises study [156], which states that SMEs provide $69 \%$ of 
all employment in Ireland and are successful due to constant training, development, and investment in innovation.

A summary of the findings which demonstrates that our all hypotheses are supported is depicted in Figure 2.

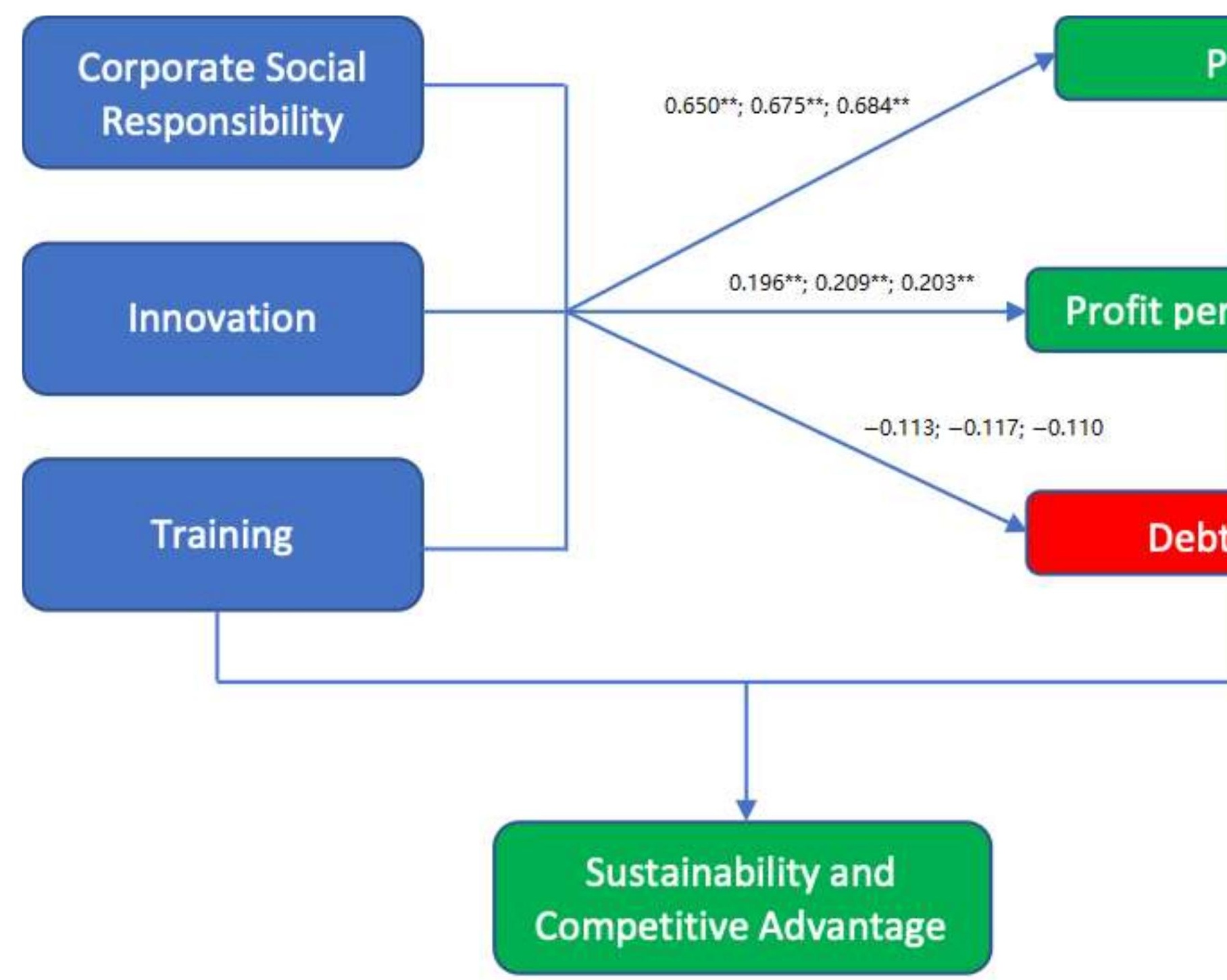

Figure 2. Results for the sustainable structural model. ${ }^{*} p<0.05$.

The results emphasize the interactions among the different financial elements of the SME's sustainable investments and the regional context [157] and also prove that SMEs perceive CSRB ${ }_{i}$, Training $B_{i}$, and Innov $B_{i}$ as important factors for their competitive advantage as proved Shen and Benson [158] by their research. Moreover, it is already well established that a significant relationship exists between Innov $B_{i}$ and CSR outcomes and between innovation and SMEs obligations to their stakeholders [159].

\section{Conclusions, Limitations and Future Research}

Our research offers new insights into the SME management literature because it can be used to understand the relevance of financial sustainable factors mechanism in different types of SMEs and the way in which SMEs can use these financial instruments in order to achieve a strategic competitive advantage. 
The importance of our study consists of an analysis of the impact of the budget related to three sustainable factors (CSR, innovation, and training) on financial results of SMEs from two important industries from the South West region of Romania. Research on SMEs has traditionally focused on human resources strategies and our research is oriented to the sustainable elements of SMEs-entities which are in continuous transformation and which are characterized by a high degree of instability (each year, many SMEs come and go from the local, national and European business environment). Moreover, the originality of the article consists of the analysis of the triple-bottom-relationships between CSR-Innovation-Training as predictors of SME sustainability based on financial results. This is important because not many sustainability studies conducted at the level of SMEs were based on complex financial factors analysis, more of them where based on a deductive or inductive analysis of the content or from a theoretical point of view [160-162].

CSR, training, and innovation is being implemented more and more by Romanian SME owners because they are starting to understand their potential. As a result, the role of all three factors as predictors of SMEs' sustainability will be increased by a new perspective that underlines the importance of their mechanisms on financial performance of SMEs. In the last years, the owners-managers of Romanian SMEs started to become aware of these advantages and invest in sustainable practices, due to the impact of these activities upon the company's financial performance.

Another practical contribution of this paper consists is the study of the financial indicators for a long period of time (eight years, from 2010 to 2017) which contributes to the reliability of the study. Our research is relevant for SMEs from the two chosen industries, the same industries used in the ISME study [156].

The main limitation of our research consists, first of all, in the fact that we only used SMEs from two industries in our sample ( $\mathrm{F}=$ Construction, $\mathrm{G}=$ Wholesale and retail, repair of motor vehicles and motorcycles) and one region of Romania (South West Oltenia Region). Another limitation is the use of financial results to measure CSR and innovation.

As for the future of our research, we aim to do the following:

(1) We want to expand our research to include SMEs from the same industries (construction industry and wholesale and trade industry) from all the development regions of Romania (North West, Centre, North East, South East, South Muntenia, West, Bucharest Ilfov).

(2) We want to study SMEs from other important industries ( $C=$ Manufacturing, I = Hotels and restaurants, $\mathrm{K}=$ Financial and insurance intermediation), taking into account the research of Hull and Rothenberg [163] who arrived at the conclusion that SMEs operating in different activity sectors may have different benefits in the pursuit of sustainable factors.

(3) Our research will further address the qualitative study of the impact of CSR on the sustainability of SMEs.

Author Contributions: Conceptualization, A.B.-S. and L.S.M.; Methodology, A.B.-S.; Software, A.B.-S.; Validation, A.B.-S. and L.S.M.; Formal Analysis, A.B.-S. and L.S.M.; Data Curation, A.B.-S. and L.S.M.; Writing-Original Draft Preparation, A.B.-S.; Writing-Review \& Editing, A.B.-S.; Visualization, L.S.M.; Supervision, A.B.-S.; Project Administration, A.B.-S. and L.S.M.

Funding: This research received no external funding.

Conflicts of Interest: The authors declare no conflict of interest.

\section{References}

1. Schaltegger, S.; Wagner, M. Sustainable entrepreneurship and sustainability innovation: Categories and interactions. Bus. Strategy Environ. 2011, 20, 222-237. [CrossRef]

2. Schiederig, T.; Tietze, F.; Herstatt, C. Green innovation in technology and innovation management-An exploratory literature review. $R$ D Manag. 2012, 42, 180-192. [CrossRef] 
3. Burlea-Schiopoiu, A.; Balan, D.A. The short memory life span of consumer: A premise for corporate socially irresponsible behaviour? In Proceedings of the Innovation Management and Education Excellence through Vision 2020, Milan, Italy, 25-26 April 2018; Volumes I-XI, pp. 1274-1286.

4. Hansen, E.G.; Klewitz, J. The role of an SME's green strategy in public private eco-innovation initiatives: The case of Ecoprofit. J. Small Bus. Entrep. 2012, 25, 451-477. [CrossRef]

5. Schaltegger, S. Sustainability as a driver for corporate economic success. Soc. Econ. 2011, 33, 15-28. [CrossRef]

6. Vilkè, R. Corporate Social Responsibility as Innovation: Recent Developments in Lithuania. Econ. Bus. 2014, 26, 119-125. [CrossRef]

7. European Commission. Implementing the Partnership for Growth and Jobs: Making Europe a Pole of Excellence on Csr. Brussels, 22.3.2006 COM (2006) 136 Final. 2006. Available online: http://eur-lex.europa.eu/ LexUriServ/LexUriServ.do?uri=COM:2006:0136:FIN:EN:PDF (accessed on 18 May 2019).

8. Russo, A.; Tencati, A. Formal vs. Informal CSR Strategies: Evidence from Italian Micro, Small, Medium-Sized, and Large Firms. J. Bus. Ethics 2009, 85, 339-353. [CrossRef]

9. Draper, S. Corporate Nirvana is the Future Socially Responsible? Industrial Society: London, UK, 2000.

10. Hitchens, D.; Thankappan, S.; Trainor, M.; Clausen, J.; De Marchi, B. Environmental Performance, Competitiveness and Management of Small Businesses in Europe. Tijdschrift Voor Economische En Sociale Geografie 2005, 96, 541-557. [CrossRef]

11. Mihai, L.S.; Burlea-Schiopoiu, A.; Mihai, M. Comparison of the leadership styles practiced by Romanian and Dutch SME owners. Int. J. Organ. Leadersh. 2017, 6, 4-16. [CrossRef]

12. Spence, L.J. Does size matter? The state of the art in small business ethics. Bus. Ethics A Eur. Rev. 1999, 8 , 163-174. [CrossRef]

13. Arvidsson, S. Communication of corporate social responsibility: A study of the views of management teams in large companies. J. Bus. Ethics 2010, 96, 339-354. [CrossRef]

14. Akben-Selcuk, E. Corporate Social Responsibility and Financial Performance: The Moderating Role of Ownership Concentration in Turkey. Sustainability 2019, 11, 3643. [CrossRef]

15. Lee, K.H.; Herold, D.M.; Yu, A.L. Small and medium enterprises and corporate social responsibility practice: A Swedish Perspective. Corp. Soc. Responsib. Environ. Manag. 2016, 23, 88-99. [CrossRef]

16. Gadenne, D.L.; Kennedy, J.; McKeiver, C. An Empirical Study of Environmental Awareness and Practices in SMEs. J. Bus. Ethics 2009, 84, 45-63. [CrossRef]

17. Williamson, D.; Lynch-Wood, G.; Ramsay, J. Drivers of Environmental Behaviour in Manufacturing SMEs and the Implications for CSR. J. Bus. Ethics 2006, 67, 317-330. [CrossRef]

18. Jenkins, H.A. Critique of Conventional CSR Theory: An SME Perspective. J. Gen. Manag. 2004, $29,37-57$. [CrossRef]

19. Murillo, D.; Lozano, J.M. SMEs and CSR: An Approach to CSR in Their Own Words. J. Bus. Ethics 2006, 67, 227-240. [CrossRef]

20. Roberts, S.; Lawson, R.; Nicholls, J. Generating Regional-Scale Improvements in SME Corporate Responsibility Performance: Lessons from Responsibility Northwest. J. Bus. Ethics 2006, 67, 275-286. [CrossRef]

21. Avram, D.O.; Kuhne, S. Implementing Responsible Business Behavior from a Strategic Management Perspective: Developing a Framework for Austrian SMEs. J. Bus. Ethics 2008, 82, 463-475. [CrossRef]

22. Fuller, T.; Tian, Y. Social and Symbolic Capital and Responsible Entrepreneurship: An Empirical Investigation of SME Narratives. J. Bus. Ethics 2006, 67, 287-304. [CrossRef]

23. Idowu, S.; Vertigas, S.; Burlea-Schiopoiu, A. Corporate Social Responsibility in Times of Crisis; Springer: Berlin, Germany, 2017. [CrossRef]

24. Friedman, A.L.; Miles, S. SMEs and the environment: Two case studies. Eco Manag. Audit. 2001, 8, $200-209$. [CrossRef]

25. Ruf, B.M.; Muralidhar, K.; Brown, R.M.; Janney, J.J.; Paul, K. An Empirical Investigation of the Relationship between Change in Corporate Social Performance and Financial Performance: A Stakeholder Theory Perspective. J. Bus. Ethics 2001, 32, 143-156. [CrossRef]

26. Aupperle, K.; Carroll, A.; Hatfield, J. An Empirical Examination of the Relationship between Corporate Social Responsibility and Profitability. Acad. Manag. J. 1985, 28, 446-463.

27. Freedman, M.; Jaggi, B. Pollution performance of firms from pulp and paper industries. Environ. Manag. 1986, 10, 359-365. [CrossRef] 
28. Preston, L.E.; O’Bannon, D.P. The Corporate Social-Financial Performance Relationship: A Typology and Analysis. Bus. Soc. 1997, 36, 419-429. [CrossRef]

29. Russo, A.; Perrini, F. Investigating stakeholder theory and social capital: CSR in large firms and SMEs. J. Bus. Ethics 2010, 91, 207-221. [CrossRef]

30. Sharma, S. Managerial Interpretations and Organizational Context as Predictors of Corporate Choice of Environmental Strategy. Acad. Manag. J. 2000, 43, 681-697.

31. Ashton, W.; Russell, S.; Futch, E. The Adoption of Green Business Practices Among Small US Midwestern Manufacturing Enterprises. J. Environ. Plan. Manag. 2017, 60, 2133-2149. [CrossRef]

32. Aragón-Correa, J.A.; Hurtado-Torres, N.; Sharma, S.; Garcia-Morales, V.J. Environmental Strategy and Performance in Small Firms: A Resource-based Perspective. J. Environ. Manag. 2008, 86, 88-103. [CrossRef]

33. Chen, M.J.; Hambrick, D.; Speed, C. Stealth, and Selective Attack: How Small Firms Differ from Large Firms in Competitive Behavior. Acad. Manag. J. 1995, 38, 453-482. [CrossRef]

34. Lepoutre, J.; Heene, A. Investigating the Impact of Firm Size on Small Business Social Responsibility: A Critical Review. J. Bus. Ethics 2006, 67, 257-273. [CrossRef]

35. Studer, S.; Welford, R.; Hills, P. Drivers and Barriers to Engaging Small and Medium-Sized Companies in Voluntary Environmental Initiatives; The Centre of Urban Planning and Environmental Management: Hong Kong, China, 2005.

36. Uhlaner, L.M.; Berent-Braun, M.M.; Jeurissen, R.J.; de Wit, G. Beyond Size: Predicting Engagement in Environmental Management Practices of Dutch SMEs. J. Bus. Ethics 2012, 109, 411-429. [CrossRef]

37. Burlea-Schiopoiu, A. An Aristotelian approach to sustainable management. In Encyclopedia of Corporate Social Responsibility; Idowu, S., Capaldi, N., Zu, L., das Gupta, A., Eds.; Springer: Berlin/Heidelberg, Germany, 2013.

38. Norbit, N.; Nawawi, A.; Salin, A.S.A.P. Corporate Social Responsibility Practices among the SMEs of Malaysia-A Preliminary Analysis. Manag. Account. Rev. 2017, 16, 17-39.

39. Park, J.; Campbell, J.M. US SMEs' Corporate Citizenship: Collectivism, Market Orientation, and Reciprocity. J. Small Bus. Entrep. 2017, 29, 120-139. [CrossRef]

40. Rahman, F.; Norman, R.T. The Effect of Firm Scale and CSR Geographical Scope of Impact on Consumers' Response. J. Retail. Consum. Serv. 2016, 28, 189-198. [CrossRef]

41. Hemingway, C.A. Personal Values as a Catalyst for Corporate Social Entrepreneurship. J. Bus. Ethics 2005, 60, 233-249. [CrossRef]

42. Nejati, M.; Quazi, A.; Amran, A.; Ahmad, N.H. Social Responsibility and Performance: Does Strategic Orientation Matter for Small Businesses? J. Small Bus. Manag. 2017, 55, 43-59. [CrossRef]

43. Spence, L.J.; Lozano, J.F. Communicating About Ethics with Small Firms: Experiences from the UK and Spain. J. Bus. Ethics 2000, 27, 43-53. [CrossRef]

44. Kurucz, E.C.; Colbert, B.A.; Wheeler, D. The Business Case for Corporate Social Responsibility. In The Oxford Handbook of Corporate Social Responsibility; Crane, A., McWilliams, A., Matten, D., Moon, J., Siegel, D., Eds.; Oxford University Press: Oxford, UK, 2008; pp. 83-112.

45. Orlitzky, M. Does Firm Size Confound the Relationship between Corporate Social Performance and Firm Financial Performance? J. Bus. Ethics 2001, 33, 167-180. [CrossRef]

46. Battaglia, M.; Bianchi, L.; Frey, M.; Iraldo, F. An Innovative Model to Promote CSR among SMEs Operating in Industrial Clusters: Evidence from an EU Project. Corp. Soc. Responsib. Environ. Manag. 2010, 17, 133-141. [CrossRef]

47. Epstein, M.J.; Schnietz, K.E. Measuring the Cost of Environmental and Labor Protests to Globalization: An Event Study of the Failed 1999 Seattle WTO Talks. Int. Trade J. 2002, 16, 129-160. [CrossRef]

48. Fonseca, L.M.; Lopes Ferro, R. Intangible Capital Does it pay to be social responsible? Portuguese SMEs feedback ISEP-IPP, School of Engineering Polytechnic of Porto and CIDEM (Portugal) 2 General Manager Bureau Veritas Certification Portugal, BUREAU VERITAS (Portugal). Intang. Cap. 2016, 12, 487-505. [CrossRef]

49. Burlea-Schiopoiu, A.; Craciun, L.; Ionascu, C. The Relationship between Financial Crisis, Corruption, and Corporate Social Responsibility in Romania. Metal. Int. 2009, 14, 108-112.

50. Torugsa, N.A.; O'Donohue, W.; Hecker, R. Capabilities, Proactive CSR and Financial Performance in SMEs: Empirical Evidence from an Australian Manufacturing Industry Sector. J. Bus. Ethics 2012, 109, 483-500. [CrossRef] 
51. Lin, L.; Hung, P.-H.; Chou, D.-W.; Lai, C.W. Financial performance and corporate social responsibility: Empirical evidence from Taiwan. Asia Pac. Manag. Rev. 2019, 24, 61-71. [CrossRef]

52. Hill, R.P.; Ainscough, T.; Shank, T.; Manullang, D. Corporate social responsibility and socially responsible investing: A global perspective. J. Bus. Ethics 2007, 70, 165-174. [CrossRef]

53. Galema, R.; Plantinga, A.; Scholtens, B. The stocks at stake: Return and risk in socially responsible investment. J. Bank. Financ. 2008, 32, 2646-2654. [CrossRef]

54. Roberts, P.; Dowling, G. Corporate Reputation and Sustained Superior Financial Performance. Strateg. Manag. J. 2002, 23, 1077-1093. [CrossRef]

55. Balan, D.A.; Burlea-Schiopoiu, A. The development of a corporate reputation metric: A customer perspective. In Major Challenges of Today's Economy; în Pînzaru, F., Zbuchea, A., Brătianu, C., Vătămănescu, E.M., Mitan, A., Eds.; Tritonic: Bucharest, Romania, 2017; pp. 595-606.

56. Klein, J.; Dawar, H. Corporate Social Responsibility and Consumers' Attributions and Brand Evaluations in a Product-Harm Crisis. Int. J. Res. Market. 2004, 21, 203-217. [CrossRef]

57. Venanzi, D.; Fidanza, B. Corporate Social Responsibility and Value Creation-Determinants and Mutual Relationships in a Sample of European Listed Firms (February 2006). Available online: https://papers.ssrn. com/sol3/papers.cfm?abstract_id=939710 (accessed on 10 December 2018).

58. Schumpeter, J.A. The Theory of Economic Development; Harvard U. Press: Cambridge, MA, USA, 1934.

59. Plotnikova, M.; Romero, I.; Martinez-Roman, J.A. Process Innovation in Small Business: The self-employed as entrepreneurs. Small Bus. Econ. 2016, 47, 939-954. [CrossRef]

60. Chan, K.F.; Lau, T. Are small business owner/managers really entrepreneurial? Entrep. Region. Dev. 1993, 5, 359-368. [CrossRef]

61. Jiménez, D.; Sanz, R. Innovación, aprendizaje organizativo y resultados empresariales. Estud. Empírico Cuad. Econ. Dir. Empresa 2006, 29, 31-56.

62. Burlea-Schiopoiu, A. The Impact of Triple Bottom Dispersal of Actions on Integrated Reporting: A Critical perspectives. In Integrated Reporting: Antecedents and Perspectives for Organizations and Stakeholders; Samuel, O.I., del Baldo, M., Eds.; Springer Nature: Basel, Switzerland, 2019; pp. 141-152. [CrossRef]

63. Damanpour, F.; Gopalakrishnan, S. The dynamics of the adoption of product and process innovations in organizations. J. Manag. Stud. 2001, 38, 45-65. [CrossRef]

64. Romero-Martinez, A.M.; Ortiz-de-Urbina-Criado, M. The role of regional location in innovativeness. Int. J. Technol. Manag. 2011, 54, 94-115. [CrossRef]

65. West, J.; Bogers, M. Leveraging external sources of innovation: A review of research on open innovation. J. Prod. Innov. Manag. 2014, 31, 814-831. [CrossRef]

66. Chesbrough, H. Open Innovation: The New Imperative for Creating and Profiting from Technology; Harvard Business School Press: Boston, MA, USA, 2003.

67. West, J.; Gallagher, S. Challenges of open innovation: The paradox of firm investment in open-source software. R D Manag. 2006, 36, 319-331. [CrossRef]

68. Dittrich, K.; Duysters, G. Networking as a means to strategy change: The case of open innovation in mobile telephony. J. Prod. Innov. Manag. 2007, 24, 510-521. [CrossRef]

69. Spithoven, A.; Clarysse, B.; Knockaert, M. Building absorptive capacity to organize inbound open innovation in traditional industries. Technovation 2010, 30, 130-141. [CrossRef]

70. Burlea-Schiopoiu, A. An Approach of the Knowledge Management for the Development of the Organisational Commitment. In Advances in Information Systems Development; Springer: New York, NY, USA, 2007; pp. 313-323.

71. Mukhamad, N.; Kiminami, A. Innovation, cooperation and business performance. J. Agribus. Dev. Emerg. Econ. 2011, 1, 75-96.

72. Belderbos, R.; Faems, D.; Leten, B.; Looy, B.V. Technological activities and their impact on the financial performance of the firm: Exploitation and exploration within and between firms. J. Prod. Innov. Manag. 2010, 27, 869-882. [CrossRef]

73. Bianchi, M.; Campodall'Orto, S.; Frattini, F.; Vercesi, P. Enabling open innovation in small-and medium-sized enterprises: How to find alternative applications for your technologies. $R$ D Manag. 2010, 40, 414-431. [CrossRef] 
74. Gao, J.; Schott, T.; Sun, X.; Liu, Y. Heterogenous Effects of Business Collaboration on Innovation in Small Enterprises: China Compared to Brazil, Indonesia, Nigera and Thailand. Emerg. Mark. Financ. Trade 2019, 55, 795-808. [CrossRef]

75. Burlea-Schiopoiu, A. The Complexity of an e-Learning System: A Paradigm for the Human Factor. In the Inter-Networked World: ISD Theory, Practice and Education; Springer: New York, NY, USA, 2009; Volume 2, pp. 267-278. [CrossRef]

76. Penalver, A.J.B.; Conesa, J.A.B.; Nieta, C.D. Analysis of Corporate Social Responsibility in Spanish Agribusiness and Its Influence on Innovation and Performance. Corp. Soc. Responsib. Environ. Manag. 2018, 25, 182-193. [CrossRef]

77. Bansal, P. Evolving sustainably: A longitudinal study of corporate sustainable development. Strateg. Manag. J. 2005, 26, 197-218. [CrossRef]

78. Gallardo-Vázquez, D.; Sánchez-Hernández, M.I. Measuring Corporate Social Responsibility for competitive success at a regional level. J. Clean. Product. 2014, 7, 14-22. [CrossRef]

79. Benito-Hernández, S.; Esteban-Sánchez, P. La influencia de las políticas de responsabilidad social y la pertenencia a redes de cooperación en el capital relacional y estructural de las microempresas. Investig. Eur. Dir. Econ. Empresa 2012, 18, 166-176. [CrossRef]

80. Kim, Y.; Brodhag, C.; Mebratu, D. Corporate Social Responsibility drive Innovation. Innov. Eur. J. Soc. Sci. Res. 2014, 27, 175-196. [CrossRef]

81. Grayson, D.; Rodriguez, M.; Lemon, M.; Jin, Z.; Slaughter, S.; Tay, S. A New Mindset for Corporate Sustainability; White Paper produced in partnership with academics from MIT, Beijing, Singapore and IESE in association with BT and Cisco Systems, 2008. Available online: https://space.lib.cranfield.ac.uk/handle/ 1826/4161 (accessed on 29 October 2019).

82. Pavelin, S.; Porter, L.A. The Corporate Social Performance Content of Innovation in the U.K. J. Bus. Ethics 2008, 80, 711-725. [CrossRef]

83. Vollebergh, H.R.J.; Kemfert, C. The Role of Technological Change for a Sustainable Development. Ecol. Econ. 2005, 54, 133-147. [CrossRef]

84. Jaffe, A.B.; Palmer, K. Environmental Regulation and Innovation: A Panel Data Study. Rev. Econ. Stat. 1997, 79, 610-619. [CrossRef]

85. McWilliams, A.; Siegel, D. Corporate Social Responsibility: A Theory of the Firm Perspective. Acad. Manag. Rev. 2001, 26, 117-127. [CrossRef]

86. Bocquet, R.; Le Bas, C.; Mothe, C.; Poussing, N. CSR, Innovation and Firm Performance in Sluggish Growth Contexts: A firm-level empirical analysis. J. Bus Ethics 2017, 146, 241-254. [CrossRef]

87. Gatignon, H.; Xuereb, J. Strategic orientation of the firm and new product performance. J. Mark. Res. 1997, 34, 77-90. [CrossRef]

88. Luo, X.; Du, S. Exploring the relationship between corporate social responsibility and firm innovation. Mark. Lett. 2015, 26, 703-714. [CrossRef]

89. Sharma, S.; Vredenburg, H. Proactive corporate environmental strategy and the development of competitively valuable organizational capabilities. Strateg. Manag. J. 1998, 19, 729-753. [CrossRef]

90. Sen, S.; Bhattacharya, C.B.; Korschun, D. The role of corporate social responsibility in strengthening multiple stakeholder relationships: A field experiment. J. Acad. Mark. Sci. 2006, 34, 158-166. [CrossRef]

91. Jansen, J.J.P.; Van Den Bosch, F.A.J.; Volberda, H.W. Exploratory innovation, exploitative innovation, and performance: Effects of organizational antecedents and environmental moderators. Manag. Sci. 2006, 52, 1661-1667. [CrossRef]

92. Nahapiet, J.; Ghoshal, S. Social capital, intellectual capital, and the organizational advantage. Acad. Manag. Rev. 1998, 23, 242-266. [CrossRef]

93. Merono-Cerdan, A.; Soto-Acosta, P.; Lopez-Nicolas, C. How do collaborative technologies affect innovation in SMEs? Int. J. E Collab. 2008, 4, 33-50. [CrossRef]

94. Tsai, K.H. Collaborative network and product innovation performance. Res. Policy 2009, 38, 765-778. [CrossRef]

95. Cumbers, A.; Mackinnon, D.; Chapman, K. Innovation, collaboration, and learning in regional clusters: A study of SMEs in the Aberdeen oil complex. Environ. Plan. A 2003, 35, 1689-1706. [CrossRef]

96. Fukugwa, N. Determining factors in innovation of small firm networks: A case of cross industry groups in Japan. Small Bus. Econ. 2006, 27, 181-193. [CrossRef] 
97. Xie, X.M.; Zeng, S.X.; Tam, C.M. Overcoming barriers to innovation in SMEs in China: A perspective based cooperation network. Innovation 2010, 12, 298-310. [CrossRef]

98. Presenza, A.; Abbate, T.; Meleddu, M.; Cesaroni, F. Small- and medium-scale Italian winemaking companies facing the open innovation challenge. Int. Small Bus. J. 2017, 35, 327-348. [CrossRef]

99. Lieberman, M.; Montgomery, D. First-mover advantages. Strateg. Manag. J. 1988, 9, 41-58. [CrossRef]

100. Sivades, E.; Dwyer, R. An examination of organizational factors influencing new products success in internal and alliance-based process. J. Mark. 2000, 64, 31-43. [CrossRef]

101. Dahl, D.; Moreau, P. The influence and value of analogical thinking during new product ideation. J. Mark. Res. 2002, 39, 47-61. [CrossRef]

102. Bigliardi, B. The effect of innovation on financial performance: A research study involving SMEs. Innov. Manag. Policy Pract. 2013, 15, 245-256. [CrossRef]

103. Cooper, R.G.; Kleinschmidt, E.J. The impact of product innovativeness on performance. J. Prod. Innov. Manag. 1991, 8, 240-251.

104. Calantone, R.J.; Vickery, S.K.; Droge, C. Business performance and strategic new product development activities: An empirical investigation. J. Prod. Innov. Manag. 1995, 12, 214-223. [CrossRef]

105. Hult, G.T.M.; Hurley, R.F.; Knight, G.A. Innovativeness: Its antecedents and impact on business performance. Ind. Mark. Manag. 2004, 33, 429-438. [CrossRef]

106. Bigliardi, B.; Dormio, A.I. An empirical investigation of innovation determinants in food machinery enterprises. Eur. J. Innov. Manag. 2009, 12, 223-243. [CrossRef]

107. Marques, C.S.; Ferreira, J. SME innovative capacity, competitive advantage and performance in a 'traditional' industrial region of Portugal. J. Technol. Manag. Innov. 2009, 4, 53-68. [CrossRef]

108. Chen, C.-J.; Huang, J.-W. Strategic human resource practices and innovation performance-The mediating role of knowledge management capacity. J. Bus. Res. 2009, 62, 104-114. [CrossRef]

109. Laursen, K.; Foss, J. New human resource management practices, complementarities and the impact on innovation performance. Camb. J. Econ. 2003, 27, 243-263. [CrossRef]

110. Lopez-Cabrales, A.; Perez-Luno, A.; Cabrera, R. Knowledge as a mediator between HRM practices and innovative activity. Hum. Resour. Manag. 2009, 48, 485-503. [CrossRef]

111. Shipton, H.; West, M.; Dawson, J.; Birdi, K.; Patterson, M. HRM as a predictor of innovation. Hum. Resour. Manag. J. 2006, 16, 3-27. [CrossRef]

112. Sheehan, M. Human resource management and performance: Evidence from small and medium-sized firms. Int. Small Bus. J. 2013, 32, 545-570. [CrossRef]

113. Antonioli, D.; Della Torre, E. Innovation adoption and training activities in SMEs. Int. J. Hum. Resour. Manag. 2016, 27, 311-337. [CrossRef]

114. Kotey, B.; Folker, C. Employee training in SMEs: Effect of size and firm type-Family and non-family. J. Small Bus. Manag. 2007, 45, 214-238. [CrossRef]

115. Hill, R.; Stewart, J. Human Resource Development in Small Organisations. J. Eur. Ind. Train. 2000, 24, 105-117. [CrossRef]

116. Burlea-Schiopoiu, A.; Remme, J. The Dangers of Dispersal of Responsibilities. Amfiteatru Econ. 2017, 19, 464-476.

117. MacMahon, J.; Murphy, E. Managerial Effectiveness in Small Enterprises: Implications for HRD. J. Eur. Ind. Train. 1999, 23, 25-35. [CrossRef]

118. Curran, J.; Blackburn, R.; Kitching, J.; North, J. Small Firms and Workforce Training: Some Results Analysis and Policy Implications from a National Survey. In Small Firms: Enterprising Futures; Ram, M., Deakins, D., Smallbone, D., Eds.; Paul Chapman: London, UK, 1997; pp. 90-101.

119. Westhead, P.; Storey, D. Management Training and Small Firm Performance: Why the Link is Weak. Int. Small Bus. J. 1996, 14, 13-25. [CrossRef]

120. Storey, D.J. Understanding the Small Business Sector; Routledge: London, UK, 1994.

121. Smith, A.J.; Boocock, G.; Loan-Clarke, J.; Whittaker, J. IIP and SMEs: Awareness, Benefits and Barriers. Pers. Rev. 2002, 31, 62-86. [CrossRef]

122. Beynon, M.J.; Jones, P.; Pickernell, D.; Packham, G. Investigating the impact of training influence on employee retention in small and medium enterprises: A regression-type classification and ranking believe simplex analysis on sparse data. Expert Syst. 2015, 32, 141-154. [CrossRef]

123. Dollinger, M. Entrepreneurship: Strategies and Resources; Irwin: Boston, MA, USA, 1995. 
124. Latham, G.P.; Frayne, C.A. Self-Management Training for Increasing Job Attendance: A Follow-Up and a Replication. J. Appl. Psychol. 1989, 74, 411-416. [CrossRef]

125. McLinden, D.J.; Davis, M.J.; Sheriff, D.E. Impact on Financial Productivity: A Study of Training Effects on Consulting Services. Hum. Resour. Dev. Q. 1993, 4, 367-375. [CrossRef]

126. Connerley, M.L. The Influence of Training on Perceptions of Recruiters' Interpersonal Skills and Effectiveness. J. Occup. Organ. Psychol. 1997, 70, 259-273. [CrossRef]

127. Klein, H.J.; Weaver, N.A. The Effectiveness of an Organizational-Level Orientation Training Program in the Socialization of New Hires. Pers. Psychol. 2000, 53, 47-66. [CrossRef]

128. Burlea-Schiopoiu, A.; Burdescu, D.D. An Integrative Approach of E-Learning: From Consumer to Prosumer. In Smart Education and E-Learning 2016, Smart Innovation, Systems and Technology; Springer International Publishing: Cham, Switzerland, 2016; Volume 59, pp. 269-279. [CrossRef]

129. Krueger, A.; Rouse, C. The Impact of Workplace Education on Earnings, Turnover, and Job Performance. J. Labor Econ. 1998, 16, 61-94. [CrossRef]

130. Birdi, K.; Clegg, C.; Patterson, M.; Robinson, A.; Stride, C.B.; Wall, T.D. The Impact of Human Resource and Operational Management Practices on Company Productivity: A Longitudinal Study. Pers. Psychol. 2008, 61, 467-501. [CrossRef]

131. Aragon, I.B.; Valle, R.S. Does Training managers pay off? Int. J. Hum. Resour. Manag. 2013, 24, 1671-1684. [CrossRef]

132. Murray, B.; Raffaele, G.C. Single-Site, Results-Level: Evaluation of Quality Awareness Training. Awareness Training. Hum. Resour. Dev. Q. 1997, 8, 229-245. [CrossRef]

133. Tzafrir, S.S. A Universalistic Perspective for Explaining the Relationship between HRM Practices and Firm Performance at Different Points in Time. J. Manag. Psychol. 2006, 21, 109-130. [CrossRef]

134. Delaney, J.; Huselid, M. The Impact of Human Resources Management Practices on Perceptions of Organizational Performance. Acad. Manag. J. 1996, 39, 949-969.

135. Black, S.; Lynch, L. Human Capital Investments and Productivity. Am. Econ. Rev. 1996, 86, $263-267$.

136. Lengermann, P.A. The Benefits and Costs of Training: A Comparison of Formal Company Training, Vendor Training, Outside Seminars, and School Based Training. Hum. Resour. Manag. 1996, 35, 361-381. [CrossRef]

137. Schonewille, M. Does Training Generally Work? Explaining Labour Productivity Effects from Schooling and Training. Int. J. Manpow. 2001, 22, 158-172. [CrossRef]

138. Lynch, L.M. Private-Sector Training and the Earnings of Young Workers. Am. Econ. Rev. 1992, 82, $299-312$.

139. Bartel, A.P. Productivity Gains from the Implementation of Employee Training Programs. Ind. Relat. 1994, 33, 411-425. [CrossRef]

140. Bartel, A.P. Training, Wage Growth, and Job Performance: Evidence from a Company Database. J. Labor Econ. 1995, 13, 401-425. [CrossRef]

141. Kidder, P.J.; Rouiller, J.Z. Evaluating the Success of a Large-Scale Training Effort. Natl. Product. Rev. 1997, 16, 79-89. [CrossRef]

142. Barrett, A.; O'Connell, P.J. Does Training Generally Work? The Returns to In Company Training. Ind. Labor Relat. Rev. 2001, 54, 647-663. [CrossRef]

143. Aragon, A.; Barba, M.I.; Sanz, R. Effects of Training on Business Results. Int. J. Hum. Resour. Manag. 2003, 14, 956-980. [CrossRef]

144. Lynch, L.M.; Black, S.E. Beyond the Incidence of Employer-Provided Training. Ind. Labor Relat. Rev. 1998, 52, 64-81. [CrossRef]

145. Frazis, H.; Gittleman, M.; Horrigan, M.; Joyce, M. Results from the 1995 Survey of Employer-Provided Training. Mon. Labor Rev. 1998, 121, 3-13.

146. D'Arcimoles, C.H. Human Resources Policies and Company Performance: A Quantitative Approach Using Longitudinal Data. Organ. Stud. 1997, 18, 857-874. [CrossRef]

147. INS—Direcția Județeană de Statistică Dolj. 2019. Available online: http://www.dolj.insse.ro (accessed on 21 March 2019).

148. Ebben, J.; Johnson, A. Bootstrapping in small firms: An empirical analysis of change over time. J. Bus. Ventur. 2006, 21, 851-865. [CrossRef]

149. Fiori, G.; Di Donato, F.; Izzo, F.N. Corporate Social Responsibility and Firms Performance-An Analysis on Italian Listed Companies. 2007. Available online: http://papers.ssrn.com/sol3/paper (accessed on 15 January 2019). 
150. Field, A. Discovering Statistics Using SPSS, 3rd ed.; Sage Publications Ltd.: London, UK, 2009.

151. Durbin, J.; Watson, G.S. Testing for serial correlation in least squares regression, II. Biometrika 1951, 30, 159-178. [CrossRef]

152. Lehmann, E.L. The Fisher, Neyman-Pearson theories of testing hypotheses: One theory or two? J. Am. Stat. Assoc. 1993, 88, 1242-1249. [CrossRef]

153. Hoffrén, J.; Apajalahti, E. Emergent eco-efficiency paradigm in corporate environment management. Sustain. Dev. 2009, 17, 233-243. [CrossRef]

154. Burlea-Schiopoiu, A. Success Factors for an Information Systems Projects Team: Creating New Context. Innov. Knowl. Manag. Twin Track Econ. Chall. Solut. 2009, 1-3, 936-941.

155. Deng, X.; Long, X. Financial Performance Gaps and Corporate Social Responsibility. Sustainability 2019, 11, 3438. [CrossRef]

156. Irish Small and Medium Enterprises (ISME). SMEs and CSR. Assessing the Level of Corporate Social Responsibility Activities and Knowledge in Irish Small and Medium Enterprises. 2015. Available online: www.isme.ie (accessed on 10 April 2019).

157. Capello, R.; Lenzi, C. Territorial patterns of innovation and economic growth in European regions. Growth Chang. 2013, 44, 195-227. [CrossRef]

158. Shen, J.; Benson, J. When CSR is a social norm: How socially responsible human resource management affects employee behaviour. J. Manag. 2016, 42, 1723-1746. [CrossRef]

159. Graafland, J.; Zhang, L. Corporate social responsibility in China: Implementation and challenges. Bus. Ethics A Eur. Rev. 2014, 23, 34-49. [CrossRef]

160. Kolk, A.; Van Tulder, R. International business, corporate social responsibility and sustainable development. Int. Bus. Rev. 2010, 19, 119-125. [CrossRef]

161. Loosemore, M.; Lim, B.T.H. Linking corporate social responsibility and organizational performance in the construction industry. Constr. Manag. Econ. 2017, 35, 90-105. [CrossRef]

162. Xia, B.; Olanipekun, A.; Chen, Q.; Xie, L.; Liu, Y. Conceptualising the state of the art of corporate social responsibility (CSR) in the construction industry and its nexus to sustainable development. J. Clean. Product. 2018. [CrossRef]

163. Hull, C.E.; Rothenberg, S. Firm performance: The interactions of corporate social performance with innovation and industry differentiation. Strateg. Manag. J. 2008, 29, 781-789. [CrossRef]

(C) 2019 by the authors. Licensee MDPI, Basel, Switzerland. This article is an open access article distributed under the terms and conditions of the Creative Commons Attribution (CC BY) license (http://creativecommons.org/licenses/by/4.0/). 